\title{
BoTANY \\ A comprehensive evaluation of pectinase, pectinmethylesterase and pectolyase activity
}

ISSN: $2220-4822$

\author{
Karishma Rajbhar*, Himanshu Dawda, Usha Mukundan \\ Department of Botany, Ramniranjan Jhunjhunwala College, Ghatkopar (West), Mumbai-400086, Maharashtra, India
}

Received: November 07, 2020

Revised: August 26, 2021

Accepted: August 28, 2021

Published: September 14, 2021

*Corresponding author:

Karishma Rajbhar,

E-mail: karishmarajbhar@

rjcollege.edu.in

\begin{abstract}
Pectin polysaccharide has galacturonic acid with linear chains of $\alpha$-(1-4)-linked D- galacturonic acid. Rhamnogalacturonan I pectins (RG-I) shows the existence of the repeating disaccharide $4-\alpha$-D-galacturonic acid-(1,2)- $\alpha$-L- rhamnose, which acts as a backbone. Chiefly, D-galactose, L-arabinose, and D-xylose are the sugars types and their proportions of neutral sugars are varied according to the origin of pectin. Pectinase, pectinmethylesterase, and pectolyase enzymes have important applications in food, textile and agricultural industries. These enzymes play an important role in the breakdown of the central part of the plant cell wall. Pectin forms the center part of the plant cell wall. Pectins are termed as a structural polysaccharide that has integrity for the steadiness of the plant cell wall. Citrate buffer of molarity 0.1 utilized to verify optimal $\mathrm{pH}$ along with temperature, for standardising enzyme activity of pectinase, pectolyase, and pectinmethylesterase by the dinitrosalicylic acid reagent method. A confirmatory check of enzyme's activity was performed on plant leaves dried particles. The impact of catechin presence in enzyme reaction was too studied. Results delve into the degradation of the plant polysaccharide by applying these enzymes. An increase in the monosaccharide galacturonic acid quantity was also significant. The highest release of the polyphenols was found due to pectolyase followed by pectinmethylesterase and pectinase. Pectinmethylesterase effect showed the maximum release of the flavonoids followed by pectinase and pectolyase which was remarkable.
\end{abstract}

KEYWORDS: Plant Cell-wall, Pectin, Catechin, DNSA Method, Monosaccharides.

\section{INTRODUCTION}

Pectin, a biopolymer of D-galacturonic acid and primary structural heteropolysaccharide in plant cell wall. Pectins polysaccharide holds numerous galacturonic acids which are straight chains of $\alpha-(1-4)$-linked D-galacturonic acid. Rhamnogalacturonan I pectins (RG-I) backbone is made of numerous repeating disaccharide 4- $\alpha$-D-galacturonic acid- $(1,2)-\alpha$-L- rhamnose. Rhamnogalacturonan I another structure have highly branched but a few numbers of complex polysaccharide of pectin is of rhamnogalacturonan II (RGII). Its backbone is completely made of many $\mathrm{D}$-galacturonic acid units (Caffall \& Mohnen, 2009; Voragen et al., 2009). Plant pectin differs in its structure, quantity, and chemical structure in each and every cell part. Studies have revealed that primary cellwall extension and plant development are greatly influenced by pectins. In middle lamellae, major components is constructed of pectin; as they facilitate cell binding together. Pectin is broken-down or degraded by the set of enzymes, throughout the progression of fruit ripening, in which the fruits turn out to be softer after the broken down of middle lamellae leading to the detachment of cells from each other. A similar progression of the cell separation is observed during the breakdown of the pectin, which appears in the abscission region of petioles of the deciduous plant at the time of leaf fall (Voragen et al., 2009; Mollet et al., 2013). Pectin forms the center of the plant cell wall. Hence, pectinase, pectinmethylesterase, and pectolyase enzymes have key applications in commercial and non- commercial food, textile and fabrics, and major in pre and post harvest agricultural products industries. Other molecules like cellulose are embedded in it. Plant cell wall stability is integral due to pectin structural polysaccharide. Pectinase, pectinmethylesterase, and pectolyase are a cluster of enzymes that break down vital central parts of the plant cell walls. Glycosidic bonds of the long carbon chains were broken-down by pectolyase. They proceed towards the substrate in a random way and also catalyze the substrate cleavage from non-reducing end. Cell-wall extension and softening of some plant tissues occur due to these enzymes, thus they are termed as prime importance for plants during maturation and storage. The random cleaving of pectin is chiefly seen near the high esterified areas of pectin which produces unsaturated

Copyright: (C) The authors. This article is open access and licensed under the terms of the Creative Commons Attribution License (http://creativecommons.org/licenses/by/4.0/) which permits unrestricted, use, distribution and reproduction in any medium, or format for any purpose, even commercially provided the work is properly cited. Attribution — You must give appropriate credit, provide a link to the license, and indicate if changes were made. 
methyloligogalacturonates through trans-elimination of glycosidic linkages (Jayani et al., 2005; Pedrolli et al., 2009).

Pectolyase mostly cleaves glycosidic linkages of polygalacturonic acid, which forms an unsaturated product called 4, 5-D-galacturonate through trans-elimination reaction (Jayani et al., 2005). Pectinase is properly known unique cluster of complex enzymes composed of polygalacturonase and pectinesterase, which ensures an elevated level of decomposition of pectic materials. This enzyme's catalyzes the break down followed by degradation of the pectic polymers that are present in the plant cell walls. It functions to hydrolyze pectin into polygalacturonic acids and ultimately to the galacturonic acid (Kashyap et al., 2001). The catalyzation is of random hydrolysis of 1-4- $\alpha-D$ galacturonic acid linkages mostly along with the insertion of water across oxygen bridge in the smooth region of pectin. They are implicated in the hydrolysis of all pectic substances. Pectinase enzymes simply act on pectin containing 50-60\% of the degree of esterification (Jayani et al., 2005; Aehle 2007). Pectinmethylesterase is pectinesterases catalyzes the de-esterification of the methoxyl group in pectin, which forms pectic acid by demethylation of pectin. The enzyme acts only on the ester group containing methyl in the galacturonate units, which is next to the non-esterified galacturonate unit (Kashyap et al., 2001). Preparations of all these pectin degrading enzymes are extensively used for clarification i.e. clearing of the fruit juices and wines for uniform consistency (Pedrolli et al., 2009). The article deals with optimising the $\mathrm{pH}$ and the temperature for pectinase, pectinmethylesterase, and pectolyase enzyme activity by using Miller's method of DNSA, 1959 and Rajbhar et al., 2015 and the effect of catechin presence in various dosages was also considered for enzymatic reaction action mechanism. Quantity of the D-galacturonic acid i.e the reducing sugar, which are released in supernatant was measured for the evaluation and analysis of pectinase, pectinmethylesterase, and pectolyase activity.

\section{MATERIALS AND METHOD}

Enzyme action for its optimal activity concerning the distinct range of $\mathrm{pH}$ and the temperature is checked by estimating sugars product i.e galacturonic acid equivalence $(\mathrm{GaE})$. $\mathrm{GaE}$ is the product of enzyme action on standard macromolecules i.e. pectin. In this evaluation, the $\mathrm{pH}$ and the temperature were be optimised and standardised by calculating the amount of sugar product equivalent to $\mathrm{GaE}$ i.e. galacturonic acid freed by means of a known amount of macromolecules pectin.

\section{Chemicals Used in Procedure}

DNSA i.e. Dinitrosalicylic acid and the crystalline phenol gained from the HI-Media (India), Rochelle salt i.e. potassium sodium tartrate, sodium hydroxide and sodium sulphite were obtained from Loba-Chemie (India). Pectin, pectinase, pectinmethylesterase, and pectolyase were provided by Sigma (India) and Novozymes (India). Instruments which were used are water bath of Equitron and V-530 Jasco spectrophotometer.

\section{Prodecure for Preparation of Reagent, Substrate and Enzyme Solution}

DNSA Reagent i.e Dinitrosalicylic Acid Reagent was prepared by solubilising solutes DNSA ( $\mathrm{lg}$ ) with crystalline phenol $(200 \mathrm{mg})$ and sodium sulphite $(50 \mathrm{mg})$ in solvent of $1 \% \mathrm{NaOH}(100 \mathrm{~mL})$ and was kept at $4^{\circ} \mathrm{C}$ till futher analysis. The reagent disintegrate due to the presence of sodium sulphite, therefore sodium sulphite was added in the course to permit extended storage but added prior to the addition of $40 \%$ Rochelle salt solution.

Aqueous pectin $(\mathrm{mg} / \mathrm{ml})$ the suspension was prepared. This solution was warmed for 5 minutes at $20^{\circ} \mathrm{C}$ on the heating mantle for obtaining a clear saturated substrate solution. Stock solution of enzyme pectinase, pectinmethylesterase, and pectolyase were made by $\mathrm{mg} / \mathrm{ml}$ in the distilled water and later in citrate buffer of the respective $\mathrm{pH}$ of buffer.

\section{Prodecure for Preparation Reaction Mixture (RM)}

RM with the $2 \mathrm{ml}$ total volume, mixture solution with enzyme volume $0.1 \mathrm{ml}$ suspended in a particular selected $\mathrm{pH}$ buffer reaching to the $1.9 \mathrm{ml}$ volume of along with the addition of the substrate solution $(0.1 \mathrm{ml})$ was prepared. RM was kept for incubation at $40^{\circ} \mathrm{C}$ for 30 minutes. Subsequent addition of the DNSA reagent $(0.5 \mathrm{ml})$ to the RM followed by incubation at $80^{\circ} \mathrm{C}$ to $85^{\circ} \mathrm{C}$ for the time of $15 \mathrm{~min}$ by using a water bath. $40 \%$ Rochelle $(0.5 \mathrm{~mL})$ salt was added when the RM in the tubes are still warm. After cooling, the RM at room temperature, the absorbance is taken of the coloured complex formed and quantification is estimated at $430 \mathrm{~nm}$ in the terms of $\mathrm{GaE}$ i.e. galacturonic acid equivalence; employing a spectrophotometer V-530 Jasco (Miller, 1959; Rajbhar et al., 2015; Sadasivam and Manickam, 1996). The standard curve was explored and plotted with $\mathrm{GaE}$ i.e galacturonic acid equivalence concentration i.e. monosaccharide in micrograms on the Y-axis against the corresponding parameter of the buffer $\mathrm{pH}$ and the temperature on the $\mathrm{X}$-axis.

\section{pH and Temperature Optimisation for Pectinase, Pectinmethylesterase, and Pectolyase}

Reaction on substrate pectin with pectinase, pectinmethylesterase, and pectolyase enzymes was evaluated by varying the $\mathrm{pH}$ of 0.1 $\mathrm{M}$ citrate buffer. Later with different temperatures in optimal $\mathrm{pH} 6.0, \mathrm{pH} 5.5$ and $\mathrm{pH} 5.4$ respectively after standardisation. Product sugar monosaccharide was estimated by a DNSA modified method in GaE i.e. galacturonic acid equivalent (430nm) (Rajbhar et al., 2015).

\section{Effect of Pectinase, Pectinmethylesterase and Pectolyase Activity on Dried Leaves of Camellia Sinensis Particles}

Camellia sinensis (Plant) leaf particles that were shade dried and used. The polyphenols were extracted from this dried leaf powder till no remnant of the polyphenol was detected by FC i.e. Folin's Ciocalteau Test (Rajbhar et al., 2016); the residual powder was again dried for the further process. This residual 
powder was considered as treated (control) sample and the test sample was with leaf particles containing polyphenol. The substrate i.e Camellia leaf particles (0.1 gram) were used for pectinase, pectinmethylesterase, and pectolyase enzyme to check their action on the Camellia leaf particles. Leaf polysaccharide substrates were prepared by using Camellia leaf powered particles (0.1 gram); these particles with before and subsequent treatment with the enzymes and then diluted with distilled water $(5 \mathrm{ml})$ followed by microwaving it for 1 minute; the polyphenols and flavonoids quantification was also performed. Estimation's of the polyphenols, the flavonoids, and the galacturonic acid (monosaccharide) was done before and after the treatment by the method as discussed in Rajbhar et al., 2016 and Rajbhar et al., 2015 respectively.

\section{RESULTS}

\section{Data Statistical Analysis}

Statistical analysis of data acquired from the studies was performed using SPSS version 22. The reported values are mean \pm SD and minimum triplicate was utilized. The results of the analysis were accomplished as $\mathrm{p}<0.05$. Duncan's Multiple Range Test (DMRT) was used in the cases where ANOVA was performed for multiple comparisons. The galacturonic acid equivalence ( $\mathrm{GaE})$ for the reducing sugar, gallic acid equivalence, catechin equivalence, rutin trihydrate equivalence, quercetin e equivalence, and ascorbic acid equivalence series have been allotted groups by using letters series of the upper case $(A>B>C \ldots)$ along with the lower case series $(\mathrm{a}>\mathrm{b}>\mathrm{c}$.) as per necessity in the graphs. The highest value reported in ascending order of alphabet in the format of $\mathrm{A}>\mathrm{AB}>\mathrm{ABC}>\mathrm{ABCD}>$. $>\mathrm{B}>\mathrm{BC}>\mathrm{BCD}>$. same with $\mathrm{P}>\mathrm{Q}>\mathrm{R}>\mathrm{S}>$. and $\mathrm{L}>\mathrm{M}>\mathrm{N}>\mathrm{O}>$. In addition, lower case alphabets are also used for distinction purposes. In the provided series, means were assigned the same letter(s) which was not significantly distinct from each other $\mathrm{p}<0.05$.

\section{DISCUSSION}

Pectinase, pectinmethylesterase, and pectolyase enzymes activity on dried leaf powdered of the Camellia sinensis shown in above graphs has the highest activity in $0.1 \mathrm{M}$ citrate buffer in the $\mathrm{pH} 6.0,5.5 \& 5.4$ at $50^{\circ} \mathrm{C}, 40^{\circ} \mathrm{C} \& 50^{\circ} \mathrm{C}$ respectively by modified DNSA method as shown in Tables 1 and 2 . Leaf powder has been treated with enzymes and polyphenol, flavonoid, and the antioxidant activity was estimated. Data revealed an increase of amount after treatment compared to control. Plant polysaccharide was degraded by this enzyme and there was a substantial increase in monosaccharide quantity i.e. Galacturonic acid. Release of polyphenols and flavonoids under 1 -minute in the microwave was estimated before and after enzymes treatment. The result displayed in the graph released the total polyphenols in gallic acid and catechin equivalence i.e GAE and CE. Total flavonoids in equivalence of quercetin and rutin trihydrate i.e QE and RTE, while total antioxidant activity in terms of ascorbic acid equivalence AAE. There was a significant effect of the enzyme on the plant intercalating

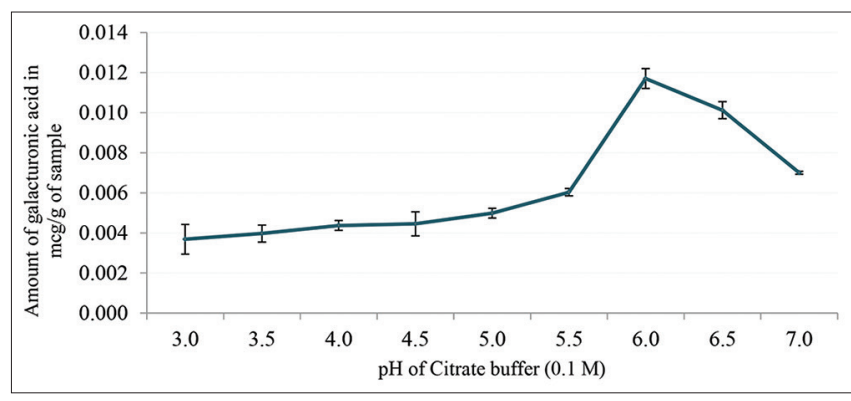

Figure 1: Pectinase enzyme activity on pectin in term of galacturonic acid equivalence

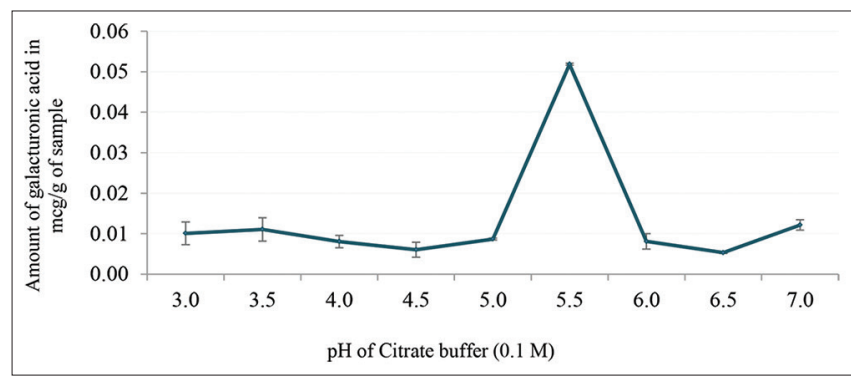

Figure 2: Pectinmethylesterase enzyme activity on pectin in term of galacturonic acid equivalence

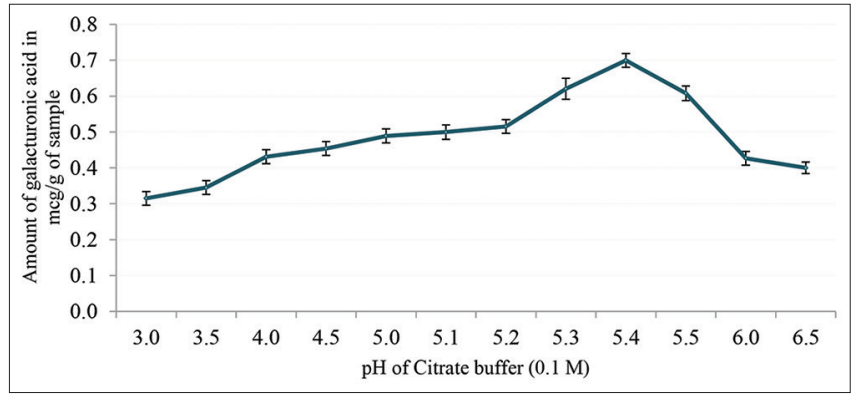

Figure 3: Pectolyase enzyme activity on pectin in term of galacturonic acid equivalence

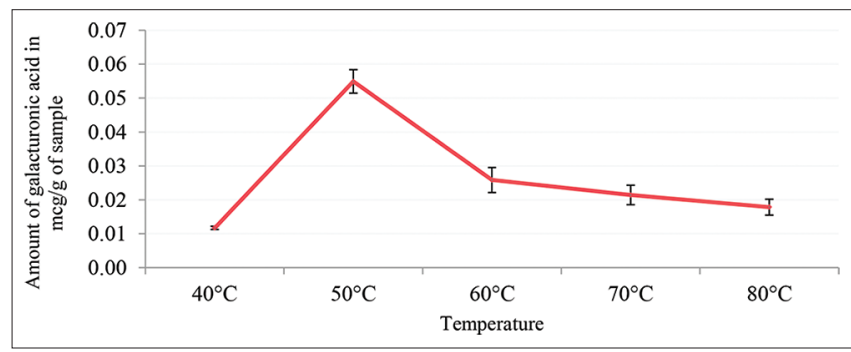

Figure 4: Pectinase enzyme activity on pectin in citrate buffer $\mathrm{pH} 6.0$ in term of galacturonic acid equivalence

polysaccharide; as the amount released of the polyphenol and flavonoid after enzymes, treatment was quite high.

It was shown in Figure 7 that polyphenol in GAE and CE in control was $39.24 \pm 0.88 \mathrm{mcg}$ and $41.63 \pm 1.15 \mathrm{mcg}$ was increased to $53.44 \pm 1.24 \mathrm{mcg}$ and $56.13 \pm 2.39 \mathrm{mcg}$ in pectinase treatment and $57.12 \pm 2.7 \mathrm{mcg}$ and $61.47 \pm 2.43 \mathrm{mcg}$ in 
pectinmethylesterase enzyme treatment. While, pectolyase showed the increased to $73.15 \pm 3.25 \mathrm{mcg}$ and $77.93 \pm 3.25 \mathrm{mcg}$ which is almost double of control. Total Flavonoids in QE and RTE in control $21.49 \pm 0.88 \mathrm{mcg}$ and $7.24 \pm 0.13 \mathrm{mcg}$ was increased to $59.9 \pm 0.7 \mathrm{mcg}$ and $8.53 \pm 0.83 \mathrm{mcg}$ in pectinase

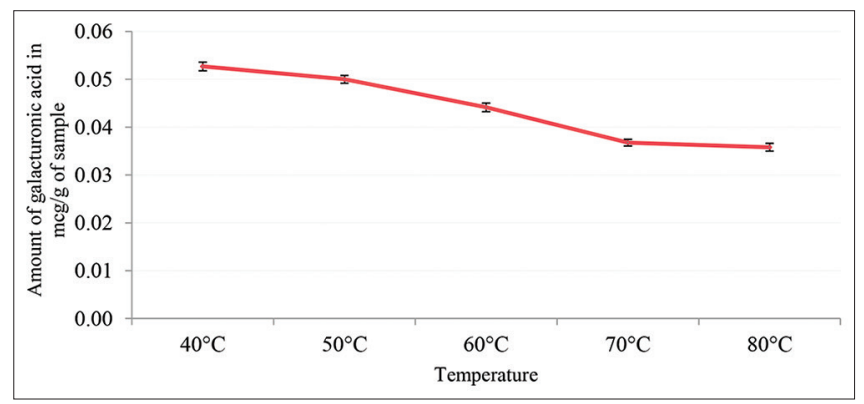

Figure 5: Pectinase enzyme activity on pectin in citrate buffer $\mathrm{pH} 5.5$ in term of galacturonic acid equivalence

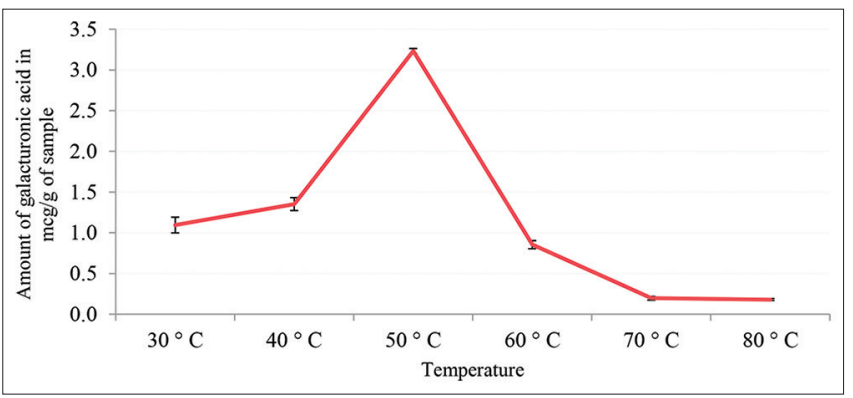

Figure 6: Pectolyase enzyme activity on pectin in citrate buffer $\mathrm{pH} 5.4$ in term of galacturonic acid equivalence

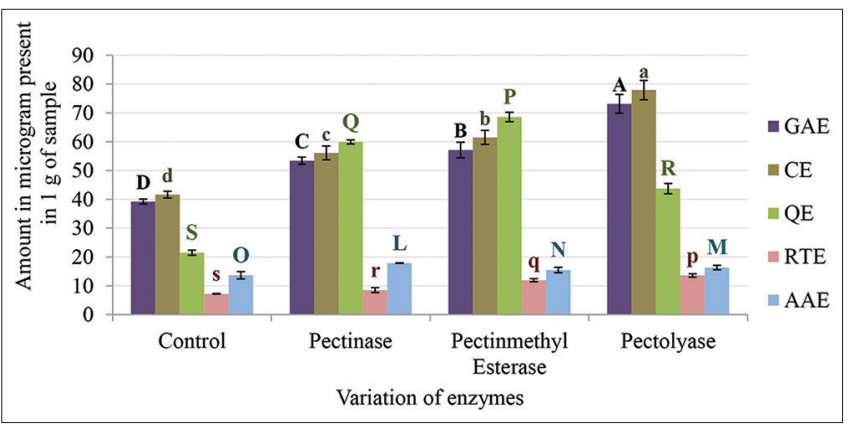

Figure 7: Pectinase, pectinmethylesterase and pectolyase enzymes activity on leaves polyphenols and flavonoids of Camellia sinensis

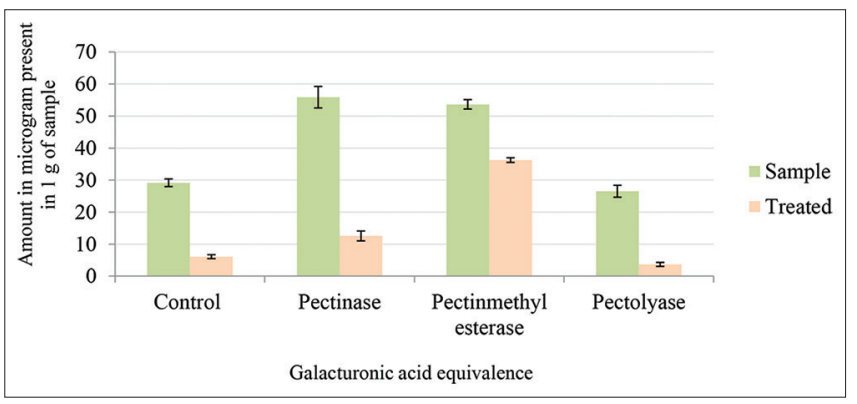

Figure 8: Pectinase, pectinmethylesterase and pectolyase enzymes activity on leaf in equivalence of sugar treatment and $68.57 \pm 1.62 \mathrm{mcg}$ and $11.94 \pm 0.55 \mathrm{mcg}$ in pectinmethylesterase enzyme treatment. While, pectolyase showed the increased to $43.75 \pm 1.77 \mathrm{mcg}$ and $13.59 \pm 0.55 \mathrm{mcg}$ which is almost double of control. Antioxidant activity of sample control $13.67 \pm 1.27 \mathrm{mcg}$ of AAE was increased to $17.88 \pm 0.09 \mathrm{mcg}$ in pectinase, $15.46 \pm 0.95 \mathrm{mcg}$ in pectinmethylesterase and $16.36 \pm 0.78 \mathrm{mcg}$ in pectolyase enzyme treatment as seen in Figure 8 and 3.3 showed an increase in galacturonic acid before and after treatment confirming disruption of cell wall structure resulting in optimum extraction. SPSS ANOVA coding affirms that pectolyase enzyme treatment showed more release of the polyphenols in gallic acid equivalent (GAE) and catechin equivalent (CE) while pectinase and pectinmethylesterase enzyme shows the highest flavonoids released in form of quercetin equivalent (QE) followed by rutin trihydrate RTE, and also the total antioxidant activity (AAE) was found maximum released in pectinase treatment.

\section{Effectt of Catechin on Pectinase, Pectinmethylesterase and Pectolyase Enzymes Activity}

Comparative graph Figures 9, 10 and 11 showed a prominent difference of catechin effect when visually observed, significance was well displayed by the catechin inhibitory effect on the enzyme. Graph of the galacturonic acid equivalence when showed in a comprehensive way the figure states a gradual reduction in the amount of the galacturonic acid equivalence in presence of the catechin ranging from 25 micrograms to 300 micrograms. It was unveiled that, as the amount of catechin was increased in the reaction mixture, it was inhibiting the activity

Table 1: Optimisation of $\mathrm{pH}$ at $40^{\circ} \mathrm{C}$ (Figure 1, 2, \& 3)

\begin{tabular}{lllc}
\hline Substrate & Enzymes & Buffer $(0.1 \mathrm{M})$ & Optimum $\mathrm{pH}$ \\
\hline Pectin & Pectinase & Citrate buffer & 6.0 \\
Pectin & Pectinmethylesterase & Citrate buffer & 5.5 \\
Pectin & Pectolyase & Citrate buffer & 5.4 \\
\hline
\end{tabular}

Table 2: Optimisation of temperature (Figure 4,5 \& 6)

\begin{tabular}{llcl}
\hline \multicolumn{2}{c}{ SubstrateEnzymes } & \multicolumn{2}{c}{$\begin{array}{c}\text { Citrate Buffer (0.1 } \\
\text { M) }\end{array}$} \\
\hline Pectin & Pectinase & pH 5.5 & $50^{\circ} \mathrm{C}$ \\
Pectin & Pectinmethylesterase & $\mathrm{pH} 6.0$ & $40^{\circ} \mathrm{C}$ \\
Pectin & Pectolyase & $\mathrm{pH} 5.4$ & $50^{\circ} \mathrm{C}$ \\
\hline
\end{tabular}

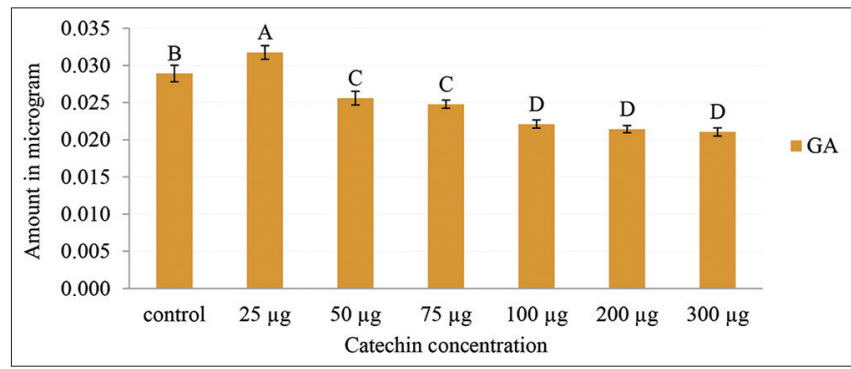

Figure 9: Effect of Catechin on pectinase activity on pectin in galacturonic acid equivalence 


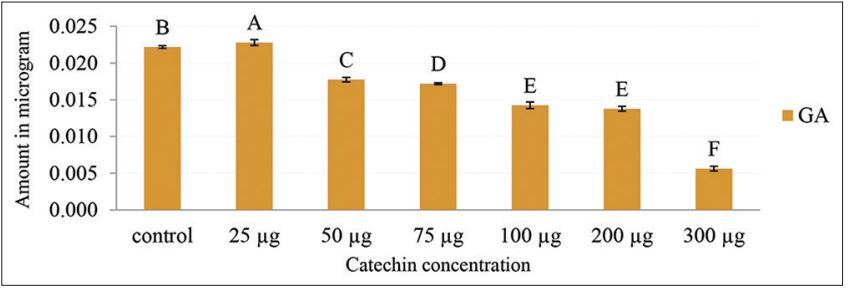

Figure 10: Effect of Catechin on pectolyase activity on pectin in galacturonic acid equivalence

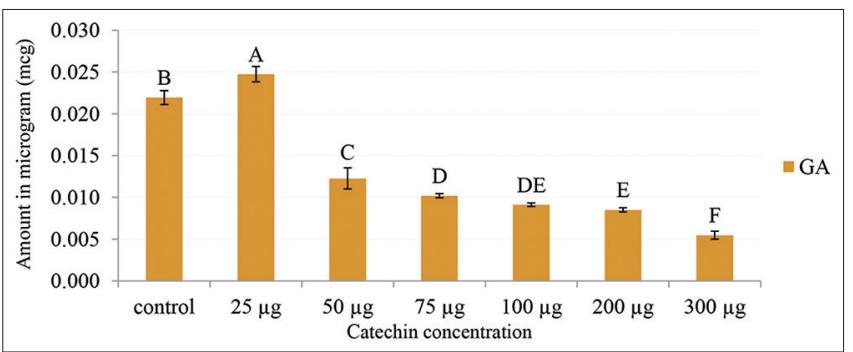

Figure 11: Effect of Catechin on pectinmethylesterase activity on pectin in galacturonic acid equivalence

of the enzyme, which is justified by biostatistical coding saying the effect is significant.

\section{CONCLUSION}

Plant polysaccharide was degraded by this enzyme and there was major boost in the galacturonic acid quantity also. The Pectolyase effect released maximum of the polyphenols followed by pectinmethylesterase and pectinase; whereas pectinmethylesterase effect released maximum of the flavonoids followed by pectinase and pectolyase which was remarkable. Inhibition of catechin has been well documented and the study revealed that, amount of the catechin presence raises from the range $25 \mu \mathrm{g}$ to $300 \mu \mathrm{g}$ it decreases enzyme activity reaction by indicating a remarkable negative effect.

\section{ACKNOWLEDGMENT}

The authors would like to thank HUL (Hindustan Unilever) for financial assistance for the collaborated research project and the fellowship provided to the first author. We are also thankful to DST for their financial support to the department of botany under the DST FIST program.

\section{REFERENCES}

Aehle, W. (2007). Enzymes in industry: production and applications. John Wiley \& Sons ( $3^{\text {rd }}$ edition). Wiley-VCH publishing.

Caffall, K. H., \& Mohnen, D. (2009). The structure, function, and biosynthesis of plant cell wall pectic polysaccharides. Carbohydrate Research, 344(14), 1879-1900. https://doi.org/10.1016/j. carres.2009.05.021

Jayani, R. S., Saxena, S., \& Gupta, R. (2005). Microbial pectinolytic enzymes: a review. Process Biochemistry, 40(9), 2931-2944. https:// doi.org/10.1016/j.procbio.2005.03.026

Kashyap, D. R., Vohra, P. K., Chopra, S., \& Tewari, R. (2001). Applications of pectinases in the commercial sector: a review. Bioresource Technology, 77(3), 215-227. https://doi.org/10.1016/S09608524(00)00118-8

Miller, G. L. (1959). Use of dinitrosalicylic acid reagent for determination of reducing sugar. Analytical chemistry, 31(3), 426-428. https://doi. org/10.1021/ac60147a030

Mollet, J. C., Leroux, C., Dardelle, F., \& Lehner, A. (2013). Cell wall composition, biosynthesis and remodeling during pollen tube growth. Plants, 2(1), 107-147. https://doi.org/10.3390/plants2010107

Pedrolli, D. B., Monteiro, A. C., Gomes, E., \& Carmona, E. C. (2009). Pectin and pectinases: production, characterization and industrial application of microbial pectinolytic enzymes. Open Biotechnology Journal, 9-18.

Rajbhar, K., Dawda, H., \& Mukundan, U. (2015). Quantitative spectrophotometric estimation of specific monosaccharides by DNSA method. Journal of Biological Science, 2(1), 112-126.

Rajbhar, K., Dawda, H., \& Mukundan, U. (2016). Comparative analysis of extraction and estimation of tea polyphenols, flavonoids and antioxidant in commercially available tea powders. Indian Journal of Plant Sciences, 5(1), 11-26.

Sadasivam, S., \& Manickam, A. (1996). Estimation of reducing sugar by dinitrosalicylic acid method. Biochemical Methods, 6(7).

Voragen, A. G., Coenen, G. J., Verhoef, R. P., \& Schols, H. A. (2009). Pectin, a versatile polysaccharide present in plant cell walls. Structural Chemistry, 20(2), 263-275. https://doi.org/10.1007/s11224-009-9442-z 